Check for updates

Cite this: RSC Adv., 2018, 8, 284

Received 23rd October 2017

Accepted 12th December 2017

DOI: 10.1039/c7ra11710h

rsc.li/rsc-advances

\section{Synthesis and characterization of poly(amide- imide)s derived from a new ortho-functional unsymmetrical dicarboxylic acid $\dagger$}

\author{
Rodrigo Javier Canto-Acosta, ${ }^{a}$ María Isabel Loría-Bastarrachea, ${ }^{a}$ Hugo Joel Carrillo- \\ Escalante, ${ }^{a}$ Emanuel Hernández-Núñez, ${ }^{\mathrm{b}}$ Manuel Aguilar-Vega (iD *a \\ and José Luis Santiago-García (DD *a
}

\begin{abstract}
A new diacid monomer containing an imide ring and a methoxy pendant group, 3-trimellitimido-4methoxybenzoic acid TMBA, was synthesized and characterized. The diacid was used to synthesize six novel poly(amide-imide)s, (PAIs), through a polycondensation reaction with different diamines in the presence of triphenylphosphite, calcium chloride, and pyridine in $\mathrm{N}$-methyl-2-pyrrolidinone. The chemical structures of the diacid monomer and poly(amide-imide)s were confirmed by FTIR and ${ }^{1} \mathrm{H}$ NMR spectroscopy. All PAls were obtained in high yield with inherent viscosities ranging from 0.32 to $0.54 \mathrm{dL} \mathrm{g}^{-1}$. They were soluble in aprotic solvents, and exhibited film forming ability. The PAl films displayed glass transition temperatures between 281 and $377^{\circ} \mathrm{C}$, as determined by dynamic mechanical analysis, and they show high thermal stability. Gas permeability results for TMBA-6FDA film show that this PAI could be an interesting material for polymeric membranes aimed to $\mathrm{CO}_{2}$ separation process.
\end{abstract}

\section{Introduction}

Poly(amide-imide)s (PAI)s combine the superior mechanical properties associated with the amine group, and the high thermal stability of the imide ring allowing a combination intended to attain high-performance polymers. ${ }^{1}$ These properties make them appropriate for different applications as substitutes for some high performance polyamides and polyimides. Generally, the synthesis of PAIs is carried out through two main routes: (a) polycondensation through amide-bond formation utilizing monomers containing a preformed imidebond; and (b) polycondensation through imide-bond formation utilizing monomers containing a preformed amide-bond. ${ }^{2}$ Based on these two approaches, the PAIs have been prepared using trimellitic anhydride (TMA), as a strategy to synthesize symmetric monomers with either preformed amide- or imidebond. ${ }^{3-7}$

The synthesis of novel PAIs with specific functionalities in the backbone may provide a way of controlling certain physical properties or special functions. Feng et al. ${ }^{8}$ have reported the preparation of biodegradable PAIs based on diacid monomers

${ }^{a}$ Unidad de Materiales, Centro de Investigación Cientifica de Yucatán, A. C. Calle 43, $x$ 32 y 34, No. 130 Col. Chuburna de Hidalgo, 97205, Mérida, Yucatán, Mexico. E-mail: jlsantia@cicy.mx; mjav@cicy.mx

${ }^{b}$ CONACYT-Departamento de Recursos del Mar, Centro de Investigación y Estudios Avanzados del IPN. Unidad Mérida, AP 73-Cordemex, 97310, Mérida, Yucatán, Mexico $\dagger$ Electronic supplementary information (ESI) available. See DOI: 10.1039/c7ra11710h containing amino acids. On the other hand, Rafiee ${ }^{7}$ synthesized a triptycene-containing dicarboxylic acid monomer, which was polymerized to obtain organosoluble PAIs with high performance properties. Sarkar et al., ${ }^{9}$ reported the synthesis of PAIs based on aromatic diamine monomers with preformed amine bonds and pendent $n$-alkyloxy side chains, these PAIs exhibited good properties to align liquid crystals (LC). Typically, PAIs are synthesized from symmetrical monomers. ${ }^{10,11}$ However, the incorporation of unsymmetrical monomers into the polymer backbone decreases packing density and crystallinity which allows obtaining soluble high performance polymers. ${ }^{12}$ Moreover, the incorporation of chemical functionalities into the PAIs backbone could lead to preparation of thermally rearranged polymers that may find use in polymer membrane technology. ${ }^{13-15}$

This study reports the synthesis and characterization of a new ortho-functional unsymmetrical dicarboxylic acid containing an imide ring and a methoxy pendant group, 3trimellitimido-4-methoxybenzoic acid. This low cost monomer is easy to obtain from a condensation reaction between trimellitic anhydride and a non-conventional aminoacid. Furthermore, to the best of our knowledge, there are not reports in the literature of its synthesis and application for polymer preparation. Additionally, the synthesis, characterization and some physical properties of six novel PAIs derived from the new diacid monomer are described. Moreover, the effect of PAI structure on pure gas permeability coefficients for the six different PAIs films was also investigated and discussed. 


\section{Experimental}

\subsection{Materials}

All reactants used for the nonconventional aminoacid monomer and PAIs synthesis were purchased from Sigma-Aldrich. The reactants 3-amino-4-methoxybenzoic acid (AMA), trimellitic anhydride (TMA), 2,4,6-trimethyl-1,3-phenylenediamine (3MPD), 2,3,5,6-tetramethyl-1,4-phenylenediamine (4MPD), 4,4'-hexafluoroisopropylidenedianiline (6FDA), 4,4'-(hexafluoroisopropylidene)bis( $p$-phenyloxy)dianiline (BAPHF), 4, $4^{\prime}$-(9-fluorenylidene)diamine (FND), 4,4'-(1,4-phenylenediisopropylidene) bisaniline (PDBI), N-methyl-2-pyrrolidinone (NMP), triphenylphosphite (TPP), and pyridine (Py) were used as received. Calcium chloride $\left(\mathrm{CaCl}_{2}\right)$ was dried under vacuum at $200{ }^{\circ} \mathrm{C}$ overnight prior to use. All other solvents and reagents were used as received without further purification.

\subsection{Characterizations}

FTIR spectra were recorded on with a Nicolet 8700 (ThermoScientific) FTIR spectrometer. The diacid monomer and poly(amide-imide)s were analysed using $\mathrm{KBr}$ pellets and films, respectively. The spectra were obtained in the transmittance mode on the range of 4000 to $400 \mathrm{~cm}^{-1}$, with 32 scans using a resolution of $4 \mathrm{~cm}^{-1}$. ${ }^{1} \mathrm{H}$ NMR spectra were acquired on a $600 \mathrm{MHz}$ Varian VNMRS spectrometer using deuterated dimethylsulfoxide (DMSO- $d_{6}$ ) as solvent with tetramethylsilane as an internal reference. Solubility tests were carried out placing $5 \mathrm{mg}$ of PAIs into $1 \mathrm{~mL}$ of solvent at room temperature followed by stirring during $24 \mathrm{~h}$. Thermogravimetric analyses (TGA) were performed using a TGA-8000 (Perkin Elmer, Inc) thermogravimetric balance. 5 to $8 \mathrm{mg}$ film samples were analysed between 50 and $800{ }^{\circ} \mathrm{C}$, at a heating rate of $10{ }^{\circ} \mathrm{C} \mathrm{min}{ }^{-1}$ under nitrogen atmosphere. Dynamic mechanical analysis (DMA) of PAIs films was performed on a DMA-Q800 (TA Instruments) the measurements were carried out using rectangular films $20 \mathrm{~mm}$ long $\times 1 \mathrm{~mm}$ wide $\times 0.1 \mathrm{~mm}$ thick in the tension mode. Measurements were performed as a function of temperature between 50 and $400{ }^{\circ} \mathrm{C}$ at a heating rate of $5{ }^{\circ} \mathrm{C} \min ^{-1}$ using a static force of $110 \mathrm{mN}$ and an $88 \mathrm{mN}$ dynamic force at $1 \mathrm{~Hz}$. A Shimadzu AGS-X universal testing machine was employed to determine the tensile properties of the films. Stress-strain curves were obtained with a $100 \mathrm{~N}$ load cell using a $1 \mathrm{~mm} \mathrm{~min}^{-1}$ strain rate according to ASTM-D882-02. Inherent viscosity $\left(\eta_{\text {inh }}\right)$ was determined with an Ubbelohde viscometer, size 50 , on $0.5 \mathrm{~g} \mathrm{dL}^{-1}$ polymer solutions in dimethylacetamide (DMAc) at $30^{\circ} \mathrm{C}$. PAIs films density was determined by the density gradient column method (Techne Corp) using calcium nitrate solutions (1.22 to $\left.1.47 \mathrm{~g} \mathrm{~cm}^{-3}\right)$. Pure gas permeability coefficients were determined using a constant volume, variable pressure permeation cell, at $35{ }^{\circ} \mathrm{C}$ and 2 atm. The effective film area was $1.13 \mathrm{~cm}^{2}$. Before each permeation test, the film was degassed for $24 \mathrm{~h}$. Gas permeability coefficients, $P$, were determined from the slope of the downstream pressure versus time plot under steady-state conditions $(\mathrm{d} p / \mathrm{d} t)_{\mathrm{ss}}$, from the following equation:

$$
P=\frac{V R^{N} l}{A R T \Delta p}\left[\frac{\mathrm{d} p}{\mathrm{~d} t}\right]_{\mathrm{ss}}
$$

where $V$ is the cell downstream volume $\left(\mathrm{cm}^{3}\right), R^{N}$ is the molar volume of a gas molecule at standard conditions (STP), $l$ and $A$ are the thickness $(\mathrm{cm})$ and effective area $\left(\mathrm{cm}^{2}\right)$ of the film exposed to the gas. $R$ is the gas constant, $T$ is the absolute temperature in $\mathrm{K}$, and $\Delta p$ is the pressure differential ( $\mathrm{cm} \mathrm{Hg}$ ) between the feed gas and the downstream of the permeation cell.

\subsection{Monomer synthesis}

2.3.1 3-Trimellitimido-4-methoxybenzoic acid (TMBA). A mixture of $1.67 \mathrm{~g}$ (10 mmol) of 3-amino-4-methoxybenzoic acid (AMA), $1.92 \mathrm{~g}$ (10 mmol) of trimellitic anhydride (TMA), and $20 \mathrm{~mL}$ of dimethylformamide (DMF) was refluxed at $160{ }^{\circ} \mathrm{C}$ during $18 \mathrm{~h}$. After cooling at room temperature, the reaction mixture was poured into $500 \mathrm{~mL}$ of cold water. The resulting precipitate was filtered off, and then washed thoroughly with water. The crude product obtained was recrystallized from isopropanol obtaining a creamy solid. (2.2 g, yield: $64.5 \%) \mathrm{Mp}$ : $312^{\circ} \mathrm{C}$. FT-IR: (KBr: $\left.\mathrm{cm}^{-1}\right)$ 3400-3300 (O-H stretch, broad), 1780 ( $\mathrm{C}=\mathrm{O}$ asymm. stretch), $1700(\mathrm{C}=\mathrm{O}$ symm. stretch $), 1380(\mathrm{C}-\mathrm{N}$ stretch), 740 (C-N bending), and 1090 (C-O-C stretch). ${ }^{1} \mathrm{H}-\mathrm{NMR}$ $\left(600 \mathrm{MHz}, \mathrm{DMSO}-d_{6}\right) \delta 8.43\left(\mathrm{~d}, J=8.0 \mathrm{~Hz}, \mathrm{H}_{\mathrm{a}}, 1 \mathrm{H}\right), 8.32\left(\mathrm{~s}, \mathrm{H}_{\mathrm{b}}\right.$, $1 \mathrm{H}), 8.09\left(\mathrm{~m}, \mathrm{H}_{\mathrm{c}}, \mathrm{H}_{\mathrm{d}}, 2 \mathrm{H}\right), 8.01\left(\mathrm{~d}, J=8.0 \mathrm{~Hz}, \mathrm{H}_{\mathrm{e}}, 1 \mathrm{H}\right), 7.34(\mathrm{~d}, J=$ $\left.8.0 \mathrm{~Hz}, \mathrm{H}_{\mathrm{f}}, 1 \mathrm{H}\right), 3.84\left(\mathrm{~s}, \mathrm{H}_{\mathrm{g}}, 3 \mathrm{H}\right) .{ }^{13} \mathrm{C}$ NMR (600 MHz, DMSO- $\left.d_{6}\right)$ $\delta 166.29\left(\mathrm{C}_{\mathrm{a}}\right), 165.91\left(\mathrm{C}_{1}\right), 165.90\left(\mathrm{C}_{\mathrm{b}}\right), 165.74\left(\mathrm{C}_{3}\right), 158.73\left(\mathrm{C}_{2^{\prime}}\right)$, $136.65\left(\mathrm{C}_{8}\right), 135.60\left(\mathrm{C}_{6}\right), 134.84\left(\mathrm{C}_{9}\right), 132.42\left(\mathrm{C}_{4^{\prime}}\right), 132.04\left(\mathrm{C}_{1^{\prime}}\right)$, $131.64\left(\mathrm{C}_{6^{\prime}}\right), 123.95\left(\mathrm{C}_{5}\right), 123.52\left(\mathrm{C}_{7}\right), 123.20\left(\mathrm{C}_{4}\right), 119.91\left(\mathrm{C}_{5^{\prime}}\right)$, $112.23\left(\mathrm{C}_{3^{\prime}}\right), 56.37\left(\mathrm{C}_{\mathrm{c}}\right)$ (Fig. $\left.\mathrm{S} 1 \dagger\right)$.

\subsection{Poly(amide-imide)s synthesis}

PAIs were synthesized by direct polycondensation of TMBA with six aromatic diamines (3MPD, 4MPD, 6FDA, FND, PDBI, BAPFH) using Yamazaki's method. ${ }^{16}$ A typical synthesis procedure for trimellitimido-methoxy-carboxylic hexafluroisopropylidene poly(amide-imide), TMBA-6FDA, was carried out as follows: a mixture of $0.68 \mathrm{~g}$ ( $2 \mathrm{mmol})$ of TMBA, $0.67 \mathrm{~g}(2 \mathrm{mmol})$ of 6FDA, previously sublimated, $0.8 \mathrm{~g} \mathrm{CaCl}_{2}$ previously dried at $200{ }^{\circ} \mathrm{C}$ overnight, $1.4 \mathrm{~mL}(17.31 \mathrm{mmol})$ of pyridine (Py), $1.4 \mathrm{~mL}(5.34 \mathrm{mmol})$ of triphenylphosphite (TPP), and $8.8 \mathrm{~mL}$ of NMP were charged into a three neck round bottom flask equipped with a nitrogen inlet/outlet, and a mechanical stirrer. The reaction mixture was stirred, and heated at $105{ }^{\circ} \mathrm{C}$ during $24 \mathrm{~h}$. After cooling at room temperature, the resulting viscous solution was poured slowly into $700 \mathrm{~mL}$ of a water/ethanol mixture $(1: 3 \mathrm{v} / \mathrm{v})$. The resulting fibrous precipitated was recuperated by filtration, washed thoroughly with methanol and hot water and dried at $100{ }^{\circ} \mathrm{C}$ under vacuum for $24 \mathrm{~h}$.

\subsection{PAIs films preparation}

PAIs dense films were prepared using a solvent casting method. Briefly, $0.3 \mathrm{~g}$ of PAI were placed in $6 \mathrm{~mL}$ of DMF; next, they were stirred until a homogeneous solution was obtained. The 
polymeric solution was filtered and poured into an aluminium mould. The solvent was slowly evaporated at $80^{\circ} \mathrm{C}$ during $24 \mathrm{~h}$. After that, the dense films were peeled off and subsequently dried under vacuum at $150{ }^{\circ} \mathrm{C}$ for $24 \mathrm{~h}$. Solvent elimination was verified by TGA in the interval of temperature between 50 and $250{ }^{\circ} \mathrm{C}$. Dense films for all PAIs were obtained with thicknesses ranging from 65 to $80 \mu \mathrm{m}$.

\section{Results and discussion}

\subsection{Monomer synthesis}

Fig. 1 shows the synthetic route for the ortho-functional unsymmetrical dicarboxylic acid, TMBA. This strategy is a simple one-pot reaction where 3-amino-4-methoxybenzoic acid was reacted with trimellitic anhydride under dimethylformamide reflux to obtain a preformed imide ring. ${ }^{17,18}$ The FTIR spectrum of TMBA monomer (Fig. 2A) showed the characteristic absorption of carboxylic acid bands $\left(3400-3300 \mathrm{~cm}^{-1}\right.$, $\mathrm{OH}-$ stretch), and imide heterocyclic ring $\left(1780 \mathrm{~cm}^{-1} \mathrm{C}=\mathrm{O}\right.$ symm, $1700 \mathrm{~cm}^{-1} \mathrm{C}=\mathrm{O}$ asymm, and $1380 \mathrm{~cm}^{-1} \mathrm{C}-\mathrm{N}$ stretch). Other important signal was observed at $1090 \mathrm{~cm}^{-1}$ corresponding to the methoxy group ether bond (C-O-C stretch). The ${ }^{1} \mathrm{H}$ NMR spectrum of TMBA was used to confirm the proposed chemical structure (Fig. 2B). First, no signal from amine groups was detected. Second, the proton signals of carboxylic acids were detected at $13.0 \mathrm{ppm}$. Finally, the signals in the range of 7.3-8.4 ppm were assigned to aromatic protons and the singlet at $3.84 \mathrm{ppm}$ corresponds to methoxy group protons present in the ortho-position of AMA. On the basis of these spectroscopic data, the synthesis of a new monomer, TMBA, was successfully achieved; thus, the new monomer was employed for the synthesis of several novel PAIs.

\subsection{Poly(amide-imide)s synthesis}

Traditionally, the phosphorylation polycondensation reaction is reported for condensation of diamines and diacids to obtain polyamides. ${ }^{16}$ Using this approach TMBA was reacted with six commercial diamines as shown in Fig. 3. 3MPD and 4MPD were considered due to the fact that they have a short and stiff structure. 6FDA and FND were selected because they present bulky pendant groups that hinder rotations of the polymer chain. On the other hand, PDBI and BAPHF were taken into account to understand the effect that long and flexible sections have on the PAIs. All polymerization reactions produce homogeneous and highly viscous solutions with up to $95 \%$ yield.

The main disadvantage of both polyamides and polyimides is their insolubility, which difficults their processing. The poly(amide-imide)s synthesized from the monomer TMBA were soluble in polar aprotic solvents at a concentration of $5 \mathrm{mg} \mathrm{mL} \mathrm{m}^{-1}$, and in some cases partially soluble in THF. They were insoluble in chlorinated solvents (Table 1). Based on these solubility results, their inherent viscosities were determined in DMAc. Inherent viscosity values range from 0.32 to $0.54 \mathrm{dL} \mathrm{g}^{-1}$ which is indicative of polymers formation with moderate molecular weights. ${ }^{7,19}$ These values were acceptable to elaborate flexible dense films by the solution casting method.

All PAIs chemical structures were confirmed by FTIR and ${ }^{1} \mathrm{H}$ NMR spectroscopy. FTIR spectra of all PAIs (Fig. S2 $\dagger$ ) show the formation of the amide bond that was easily identified due to<smiles>CCCCCC(C)C(=O)OC(=O)c1ccc2c(c1)C(=O)N(c1cc(C(=O)O)ccc1OC)C2=O</smiles>

Fig. 1 Scheme of TMBA monomer synthesis.
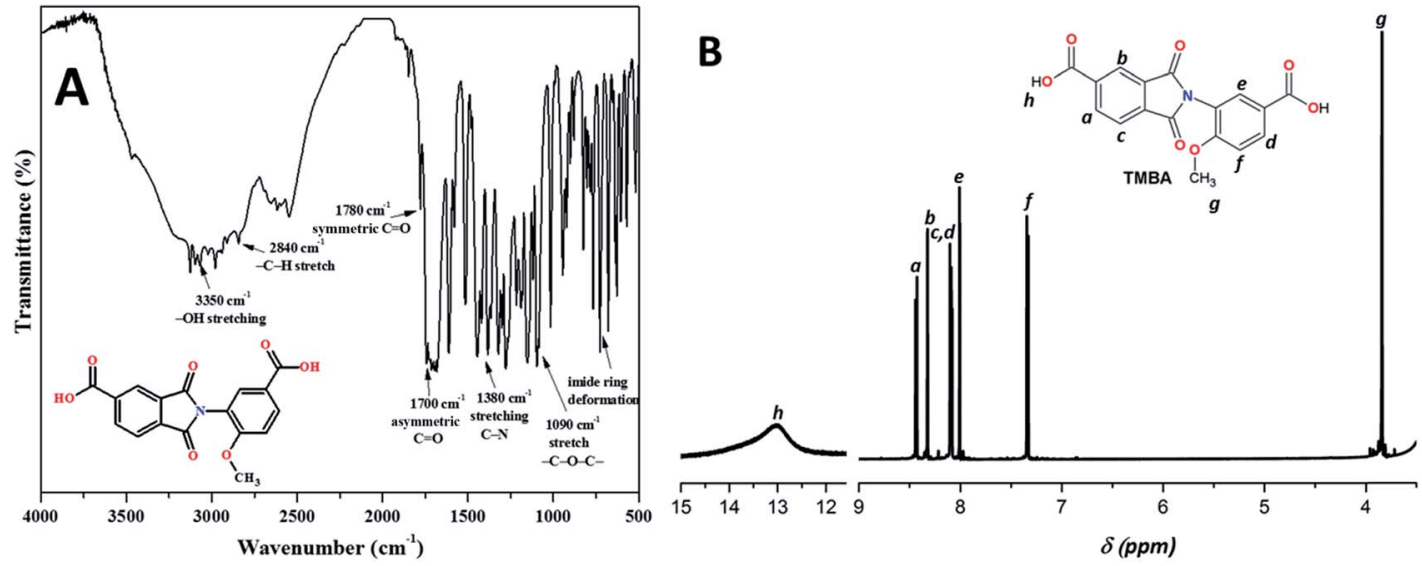

Fig. 2 (A) FTIR and (B) ${ }^{1} H$ NMR TMBA spectra. 
<smiles>[R]c1c(C)cc(C)c(C)c1C</smiles>

Fig. 3 Synthesis of poly(amide-imide)s.

Table 1 PAls solubility and inherent viscosity ${ }^{a}$

\begin{tabular}{|c|c|c|c|c|c|c|c|c|c|}
\hline PAI & NMP & DMAc & DMF & DMSO & THF & DCM & TCE & $\mathrm{CHCl}_{3}$ & $\eta_{\text {inh }}\left(\mathrm{dL} \mathrm{g}^{-1}\right)$ \\
\hline TMBA-4MPD & + & + & + & + & - & - & - & - & 0.46 \\
\hline TMBA-6FDA & + & + & + & + & \pm & - & - & - & 0.54 \\
\hline TMBA-FND & + & + & + & + & - & - & - & - & 0.47 \\
\hline
\end{tabular}

${ }^{a}$ Measured in DMAc $\left(0.5 \mathrm{~g} \mathrm{dL}^{-1}\right)$ at $30^{\circ} \mathrm{C}$. Solubility $\left(5 \mathrm{mg} \mathrm{mL}^{-1}\right):+$, soluble, - , insoluble, \pm , partially soluble at room temperature.

the presence of characteristic bands at $3300 \mathrm{~cm}^{-1}(\mathrm{~N}-\mathrm{H}$ stretching) and at $1660 \mathrm{~cm}^{-1}(\mathrm{C}=\mathrm{O}$ stretching). Moreover, the resulting PAIs also showed signals at $1780 \mathrm{~cm}^{-1}$ and $1720 \mathrm{~cm}^{-1}$ $(\mathrm{C}=\mathrm{O}$ symmetrical and asymmetrical stretching), and at $1370 \mathrm{~cm}^{-1}$ (C-N stretching) corresponding to the imide ring, and at $2930 \mathrm{~cm}^{-1}$ (C-H stretching) of methyl groups present in TMBA. Fig. 4 shows, as an example, the FTIR spectrum of the poly(amide-imide) TMBA-6FDA. Furthermore, in the ${ }^{1} \mathrm{H}$ NMR spectra of all PAIs (Fig. S3A and S3B $\dagger$ ) there were observed two signals in the region between 10.2 and $10.9 \mathrm{ppm}$ and 9.8 to $10.5 \mathrm{ppm}$, these signals were attributed to amide protons (-CO$\mathrm{NH}-$ ) formed by the condensation reaction between diacids and diamines; moreover, these results confirmed the unsymmetrical structure of TMBA, where the amide proton downfield corresponds to TMA, while the amide proton observed upfield corresponds to the AMA moiety. Fig. 5 shows, as an example, the assignments of protons for the repeating unit from poly(amideimide) TMBA-6FDA.

\subsection{Thermal properties}

Thermal behaviour of all PAIs was evaluated by DMA and TGA techniques under nitrogen atmosphere the results are summarized in Table 2. Glass transition temperature $\left(T_{\mathrm{g}}\right)$ was 


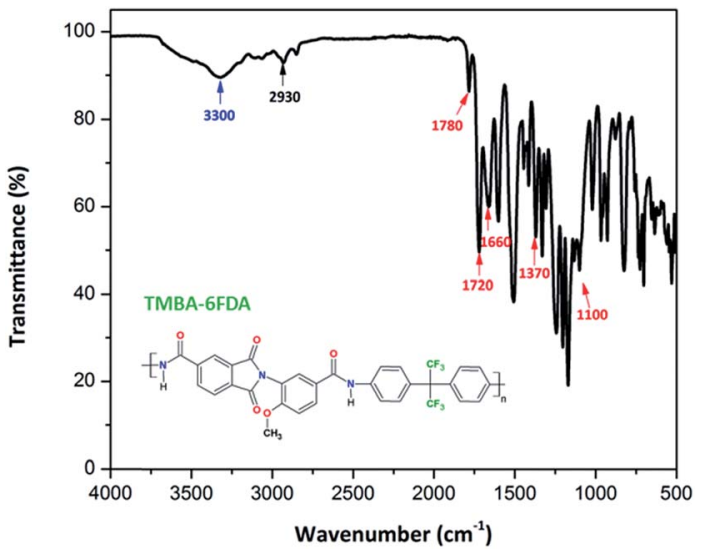

Fig. 4 FTIR spectrum of PAI TMBA-6FDA.

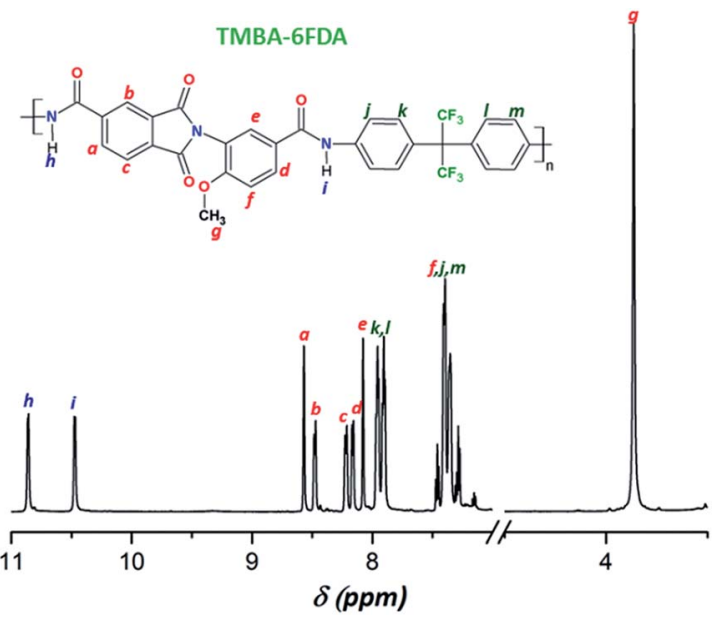

Fig. $5{ }^{1} \mathrm{H}$ NMR spectrum of PAI TMBA-6FDA.

obtained from the peak in tan delta curves from DMA analysis (Fig. S4 $\dagger$ ). ${ }^{20} T_{\mathrm{g}}$ 's of poly(amide-imide)s were in the range of 281 to $377{ }^{\circ} \mathrm{C}$. The $T_{\mathrm{g}}$ depended on the diamine moiety structure. When the diamine is rigid and bulky, such as FND, the poly(amide-imide) TMBA-FND displayed the highest $T_{g}$; whereas when the diamine has flexible linkages, as is the case of the poly(amide-imide) TMBA-BAPHF, $T_{\mathrm{g}}$ was the lowest due to a higher flexibility associated with the ether $(\mathrm{C}-\mathrm{O}-\mathrm{C})$ groups present in this diamine moiety. On the other hand, all aromatic PAIs exhibited two thermal degradation steps (Table 2, Fig. 6, and Fig. S5 $\dagger$ ). The first weight loss was observed around 368 up to $426^{\circ} \mathrm{C}$ and it was ascribed to the elimination of the methoxy pendant groups present in the TMBA, which could be converted to benzoxazole rings by thermal rearrangement; ${ }^{22-24}$ meanwhile the second weight loss in the range of 496 to $592{ }^{\circ} \mathrm{C}$ was ascribed to the polymer backbone degradation. Moreover, the char yield at $800{ }^{\circ} \mathrm{C}$ was found in the range of 53 to $56 \mathrm{wt} \%$. The later data were employed to calculate the limiting oxygen index (LOI). Based on LOI values obtained on PAIs these polymers can be classified as auto-extinguishing materials..$^{7,25,26}$

\subsection{Mechanical properties}

Mechanical properties of PAIs films, obtained by the solvent casting method, were characterized by the tensile test and the results are summarized in Table 3. Tensile properties of the PAI TMBA-3MPD were not measured because the film was highly brittle. The other PAIs films present tensile strengths ranging from 52 to $71 \mathrm{MPa}$. Tensile modulus was found to be between 1.3 and $1.8 \mathrm{GPa}$ while elongation at break percent lies in between 3.5 and $9.0 \%$. These results are consistent with data previously reported in the literature for aromatic PAIs and suggest that the PAIs dense films based on TMBA present high mechanical properties. ${ }^{6,7,10,17}$

\subsection{Gas permeability coefficient}

Polymeric gas separation membranes have great potential for industrial gas separation process because of their costeffectiveness and lower energy requirements in applications such as natural gas sweeting. ${ }^{27-29}$ The potential application of different poly(amide-imide)s as gas separation membranes has been previously reported. ${ }^{30-32}$ In here, pure gas permeability coefficients of the novel PAIs films prepared were tested using a constant-volume, variable pressure gas permeation cell at $35{ }^{\circ} \mathrm{C}$ and $2 \mathrm{~atm}$. Results of pure gas permeability coefficients for $\mathrm{He}, \mathrm{O}_{2}, \mathrm{CO}_{2}, \mathrm{CH}_{4}$ and $\mathrm{N}_{2}$ for the six PAIs and a commercial PAI (Torlon) for comparison are given in Table 4. Gas permeability coefficients for the TMBA-based PAIs decrease in the order $P_{\mathrm{He}}>P_{\mathrm{CO}_{2}}>P_{\mathrm{O}_{2}}>P_{\mathrm{N}_{2}}>P_{\mathrm{CH}_{4}}$. This behaviour agrees with the kinetic diameter order of the gases evaluated: $\mathrm{He}(2.6 \AA)>$ $\mathrm{CO}_{2}(3.3 \AA)>\mathrm{O}_{2}(3.46 \AA)>\mathrm{N}_{2}(3.64 \AA)>\mathrm{CH}_{4}(3.8 \AA)$.

Table 2 Thermal properties of PAls

\begin{tabular}{|c|c|c|c|c|c|}
\hline PAIs & $T_{\mathrm{g}}\left({ }^{\circ} \mathrm{C}\right), \mathrm{DMA}^{a}$ & $T_{\max 1}^{b}\left({ }^{\circ} \mathrm{C}\right)$ & $T_{\max 2}\left({ }^{\circ} \mathrm{C}\right)$ & Char yield $^{c}(\%)$ & $\mathrm{LOI}^{d}$ \\
\hline TMBA-3MPD & 353 & 373 & 516 & 59.7 & 41.3 \\
\hline TMBA-4MPD & 367 & 368 & 496 & 59.7 & 41.3 \\
\hline TMBA-FND & 377 & 426 & 592 & 66.3 & 44.0 \\
\hline TMBA-PDBI & 286 & 419 & 541 & 55.0 & 39.4 \\
\hline TMBA-BAPHF & 281 & 419 & 575 & 56.6 & 40.1 \\
\hline
\end{tabular}

${ }^{a}$ Measured by DMA at heating rate of $5{ }^{\circ} \mathrm{C} \mathrm{min}{ }^{-1}$ and $1 \mathrm{~Hz} .{ }^{b} T_{\max }$, onset of decomposition temperature of the two events observed. ${ }^{c}$ At $800{ }^{\circ} \mathrm{C}$ in $\mathrm{N}_{2}$ atmosphere. ${ }^{d}$ Limiting oxygen index (LOI) calculated from equation LOI $=17.5+0.4$ (char yield). ${ }^{21}$ 


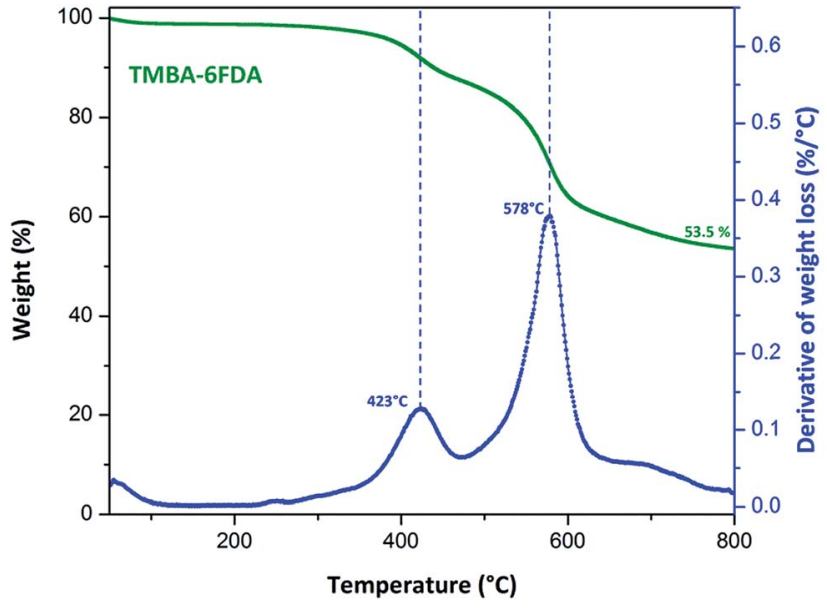

Fig. 6 TGA and DTGA curves of PAI TMBA-6FDA.

Table 3 PAls mechanical properties under tension

\begin{tabular}{llll}
\hline PAI & $\begin{array}{l}\text { Tensile modulus } \\
(\mathrm{GPa})\end{array}$ & $\begin{array}{l}\text { Tensile strength } \\
(\mathrm{MPa})\end{array}$ & $\begin{array}{l}\text { Elongation at } \\
\text { break (\%) }\end{array}$ \\
\hline TMBA-3MPD & - & - & - \\
TMBA-4MPD & 1.3 & 64.1 & 6.4 \\
TMBA-6FDA & 1.6 & 63.9 & 6.4 \\
TMBA-FND & 1.8 & 55.9 & 3.5 \\
TMBA-PDBI & 1.4 & 52.0 & 4.5 \\
TMBA-BAPHF & 1.4 & 71.9 & 9.0
\end{tabular}

Table 4 PAls pure gas permeability coefficients

\begin{tabular}{llllllll}
\hline & \multicolumn{9}{c}{ Permeability $^{a}, P,($ Barrer) } & & \multicolumn{2}{l}{$\alpha^{b}$} \\
\cline { 2 - 4 } PAI & $\mathrm{He}$ & $\mathrm{CO}_{2}$ & $\mathrm{O}_{2}$ & $\mathrm{~N}_{2}$ & $\mathrm{CH}_{4}$ & & $\mathrm{CO}_{2} / \mathrm{CH}_{4}$ \\
\hline TMBA-3MPD & 14.5 & $\mathbf{2 . 4}$ & 0.73 & 0.38 & 0.37 & 6.5 \\
TMBA-4MPD & 27.3 & $\mathbf{5 . 8}$ & 1.35 & 0.56 & 0.52 & \\
TMBA-6FDA & $\mathbf{4 6 . 5}$ & $\mathbf{1 2 . 3}$ & $\mathbf{3 . 1 0}$ & $\mathbf{0 . 7 3}$ & $\mathbf{0 . 6 4}$ & $\mathbf{1 9 . 2}$ \\
TMBA-FND & 29.6 & $\mathbf{9 . 1}$ & 2.43 & 1.12 & 1.11 & 8.2 \\
TMBA-PBDI & 19.0 & $\mathbf{7 . 4}$ & 1.63 & 0.48 & 0.48 & $\mathbf{1 5 . 4}$ \\
TMBA-BAPHF & 28.3 & $\mathbf{1 0 . 9}$ & 2.41 & 0.64 & 0.58 & $\mathbf{1 8 . 8}$ \\
Torlon $^{33}$ & 3.73 & $\mathbf{0 . 5 4}$ & 0.13 & 0.018 & 0.013 & 41.5
\end{tabular}

${ }^{a} 1$ Barrer $=10^{-10} \mathrm{~cm}^{3}$ (STP) $\mathrm{cm} \mathrm{s}^{-1} \mathrm{~cm}^{-2} \mathrm{cmHg}^{-1}$, evaluated at $35{ }^{\circ} \mathrm{C}$ and 2 atm. ${ }^{b}$ Ideal separation factor.

PAIs films showed significant changes on pure gas permeability coefficient depending on the kind of diamine used for its preparation. For example, $\mathrm{CO}_{2}$ permeability coefficients, $P_{\mathrm{CO}_{2}}$ decrease in the order TMBA-6FDA $>$ TMBA-BAPHF $>$ TMBA-FND $>$ TMBA-PDBI > TMBA-4MPD > TMBA-3MPD. Interestingly, TMBA-6FDA film also shows the highest ideal selectivity for the gas pair $\mathrm{CO}_{2} / \mathrm{CH}_{4}$. However, its selectivity was lower than the one reported for Torlon. ${ }^{33}$ Gas permeability in a dense polymeric film is related with structural parameters which are responsible of molecular packing such as fractional free volume.

The concept of fractional free volume (FFV) has been helpful to explain the gas permeability behaviour in polymeric membranes. FFV is defined as:
Table 5 PAls density and fractional free volume

\begin{tabular}{|c|c|c|c|c|}
\hline PAI & $\rho\left(\mathrm{g} \mathrm{cm}^{-3}\right)$ & $V\left(\mathrm{~cm}^{3} \mathrm{~mol}^{-1}\right)$ & $V_{\mathrm{wd}}\left(\mathrm{cm}^{3} \mathrm{~mol}^{-1}\right)$ & FFV \\
\hline TMBA-3MPD & 1.279 & 356.14 & 240.58 & 0.122 \\
\hline TMBA-4MPD & 1.278 & 367.37 & 254.25 & 0.100 \\
\hline TMBA-6FDA & 1.420 & 450.35 & 288.77 & 0.166 \\
\hline TMBA-FND & 1.288 & 507.53 & 332.77 & 0.148 \\
\hline TMBA-PDBI & 1.248 & 520.59 & 347.57 & 0.132 \\
\hline TMBA-BAPHF & 1.391 & 592.16 & 386.37 & 0.152 \\
\hline
\end{tabular}

in which, $V$ is the specific volume of the polymer, calculated as:

$$
V=\frac{1}{\rho}
$$

where $\rho$ is the measured density given in Table 5 , and $V_{\mathrm{o}}$ is the polymer chain occupied volume that was calculated from:

$$
V_{\mathrm{o}}=1.3 V_{\mathrm{W}}
$$

where, $V_{\mathrm{W}}$ is the van der Waals volume of the polymer chain repeating unit, that was calculated by Bondi's group contribution method..$^{34,35}$

In the present work, PAIs gas permeability coefficients show a good correlation with FFV. In particular, TMBA-6FDA and TMBA-BAPHF, that contain the bulky $-\mathrm{CF}_{3}$ group, presented higher FFV which is associated to higher pure gas permeability. They also show the best $\mathrm{CO}_{2} / \mathrm{CH}_{4}$ ideal selectivity which is linked to the presence of $-\mathrm{CF}_{3}$ groups.

\section{Conclusions}

In summary, a new ortho-functional unsymmetrical dicarboxylic acid, 3-trimellitimido-4-methoxybenzoic acid (TMBA) was successfully synthesized and its chemical structure confirmed. Moreover, novel poly(amide-imide)s were prepared from TMBA with six aromatic diamines by a direct polycondensation reaction using triphenyl phosphite and pyridine. The PAIs were soluble in polar aprotic solvents. They were able to form dense films with good mechanical properties and they present high thermal stability and LOI. They have pure gas permeability coefficient one order of magnitude larger than those of commercial poly(amide-imide) Torlon. TMBA-6FDA films show both higher pure gas permeability coefficients and higher ideal selectivity for the gas pair $\mathrm{CO}_{2} / \mathrm{CH}_{4}$ in the evaluated membranes; thus, this particular poly(amide-imide), TMBA6FDA, shows a potential for application as a membrane for gas separation processes.

\section{Conflicts of interest}

There are no conflicts to declare. 


\section{Acknowledgements}

The authors thankfully acknowledge the financial support from CONACYT-México grant number 206998. R. J. Canto-Acosta thanks CONACYT-México for the fellowship 576647. The authors thank Dr Patricia Quintana for the access to LANNBIOCINVESTAV to carry out NMR measurements, and M. Sc. Rosalba Gamboa Magaña for her technical support in the FTIR analysis.

\section{References}

1 J. M. Dodda and P. Bêlský, Eur. Polym. J., 2016, 84, 514.

2 E. Ravve, Principles of polymer chemistry, Springer, New York, 3rd edn, 2012.

3 P. S. Patil, R. R. Pal, M. M. Salunkhe, N. N. Maldar and P. P. Wadgaonkar, Eur. Polym. J., 2007, 43, 5047.

4 I. Bacosca, E. Hamciuc, M. Bruma and M. Ignat, React. Funct. Polym., 2011, 71, 905.

$5 \mathrm{H}$. Behniafar and S. Mohammadparast-delshaad, Polym. Degrad. Stabil., 2012, 97, 228.

6 S.-H. Hsiao, W. Guo, T.-H. Tsai and Y.-T. Chiu, J. Polym. Res., 2014, 21, 391.

7 Z. Rafiee, J. Macromol. Sci., Part B: Phys., 2015, 54, 749.

8 J. Feng, F. He, Z. Yang and J. Yao, Polym. Degrad. Stabil., 2016, 129, 231.

9 A. Sarkar, A. S. More, P. P. Wadgaonkar, G. J. Shin and J. C. Jung, J. Appl. Polym. Sci., 2007, 105, 1793.

10 C.-P. Yang, S.-H. Hsiao and H.-C. Hsiao, J. Polym. Sci., Part A: Polym. Chem., 1999, 37, 69.

11 S.-H. Hsiao, C.-Y. Teng and Y.-R. Kung, RSC Adv., 2015, 5, 93591.

12 L. Cheng and X. G. Jian, J. Appl. Polym. Sci., 2004, 92, 1516.

13 H. B. Park, S. H. Han, C. H. Jung, Y. M. Lee and A. J. Hill, J. Membr. Sci., 2010, 359, 11.

14 S. H. Han, N. Misdan, S. Kim, C. M. Doherty, A. J. Hill and Y. M. Lee, Macromolecules, 2010, 43, 7657.
15 R. Guo, D. F. Sanders, Z. P. Smith, B. D. Freeman, D. R. Paul and J. E. McGrath, J. Mater. Chem., 2013, 1, 6063.

16 N. Yamazaki, F. Higashi and J. Kawabata, J. Polym. Sci., Polym. Chem. Ed., 1974, 12, 2149.

17 S. H. Hsiao, C.-P. Yang, C.-W. Chen and G. S. Liou, J. Polym. Res., 2005, 12, 289.

18 L. H. Tagle, C. A. Terraza, A. Tundidor-Camba and F. A. Lara, Polym. Bull., 2014, 71, 1031.

19 C. Hamciuc, E. Hamciuc, M. Homocianu, A. Nicolescu and I.-D. Carja, Dyes Pigm., 2015, 114, 110.

20 P. K. Gutch, L. K. Pandey and C. Saxena, J. Appl. Polym. Sci., 2008, 110, 203.

21 D. W. van Krevelen and K. Ten Nijenhius, Properties polymer, completely rev., Amsterdam, 4th edn, 2009.

22 K. H. Park, M.-A. Kakimoto and Y. Imai, J. Polym. Sci., Part A: Polym. Chem., 1998, 36, 1987.

23 J.-H. Chang, K. M. Park, S.-O. Lee and J. B. Oh, J. Polym. Sci., Part A: Polym. Chem., 2000, 38, 2537.

24 B. Jarzabek, M. Wójtowicz and A. Wolinska-Grabczyck, Macromol. Chem. Phys., 2015, 216, 2377.

25 R. Balasubramanian, K. Kumutha and M. Sarojadevi, Polym. Bull., 2016, 73, 309.

26 S. Mondal and N. Das, RSC Adv., 2014, 4, 61383.

27 R. N. Baker, Ind. Eng. Chem. Res., 2002, 41, 139.

28 D. F. Sanders, Z. P. Smith, R. Guo, L. M. Robeson, J. M. McGrath, D. R. Paul and B. D. Freeman, Polymer, 2013, 54, 4729.

29 J. K. Adewole and A. L. Ahmad, J. Polym. Res., 2017, 24, 70.

30 D. Fritsch and K.-V. Peinemann, J. Membr. Sci., 1995, 99, 29.

31 Z.-K. Xu, M. Böhning and J. Springer, Polymer, 1997, 38, 581.

32 S.-H. Huang, C.-C. Hu, K.-R. Lee, D.-J. Liaw and J.-Y. Lai, Eur. Polym. J., 2006, 42, 140.

33 W. F. Yong, F. Y. Li, T. S. Chung and Y. W. Tong, J. Membr. Sci., 2014, 462, 119.

34 A. Bondi, J. Phys. Chem., 1964, 68, 441.

35 J. Y. Park and D. R. Paul, J. Membr. Sci., 1997, 125, 23. 